FACTA UNIVERSITATIS

Series: Visual Arts and Music Vol. 4, N 1,2018 , pp. 1 - 10

https://doi.org/10.22190/FUVAM1801001K

Original scientific paper

\title{
MUSIC AND SUSTAINABILITY: ŠKOFJA LOKA, A PASSION PLAY IN AN INTERRELIGIOUS CONTEXT
}

\author{
UDC 784.4 (497.4 Škofja Loka)
}

\section{Franc Križnar}

Musicologist, Škofja Loka, Slovenia

\begin{abstract}
The rudimentary beginnings of the Škofja Loka Passion Play (̌́LPP) can be found in Slovene Lenten songs. Each year's procession of the SLLPP, was seen on Good Friday or at the end of the time of fasting within the frame of the church calendar. The repertoire of Slovene folk and art songs is very rich, therefore it is not strange that the author, Father Romuald Štandreški, a Capuchin, (1715-1721) was to be the author of the $\check{S} L P P$ who would be familiar to the Slovene folk songs.
\end{abstract}

Key words: Slovene Lenten songs, procession, Father Romuald of St. Andrea

\section{INTRODUCTION}

The passion has unitary significance among the three most widespread European or at least Slavic religions (Christianity, Protestantism and Orthodoxy). Besides the passion and the suffering, we know that there is always art, drama, music, and/or literature of passion as well as an oratorio, i.e. the vocal-instrumental music form or a piece of music of the Gospel texts of the Passions of Christ. Passion is about the suffering (Lat. passio) and in the Western Christian liturgy it means writing down Jesus' (Christ) passion and his death in the four gospels, i.e. the great news of victory on the battle-field. Christianity itself is about the special arrival of the Redeemer and the New Testament writings of Jesus of Nazareth, about his life and works in the 1st century. There are four Gospels all together and Evangelism or Jesus-Christ lesson about the imminent arrival of God's kingship. All of them are read and/or played during the Passion Week before Easter. A wider significance is all about Christianity described as the life, the passion and the work of a person who is sacred and glorious in a particular religion.

The passions took place in ancient Egypt in the $2^{\text {nd }}$ century before Christ. They are about the life and work of Osiris, the Egyptian God of death. Later the passions appeared

Received May, 2018 / Accepted September 2018

Corresponding author: Franc Križnar

Škofja Loka, Slovenia

E-mail: franc.kriznar@siol.net 
in Islam, too. There we can find out about the passion of the prophet Hussein that took place on the $10^{\text {th }}$ day in month Muharram. It was named Ashura and it is their central holiday in the ritual year, and in Christianity it is about the Christian Holy Scripture.

\section{THE PASSIONS AND ŠKOFJA LOKA PASSION PLAY (ŠLPP)}

The passion was developed from the liturgical drama, one of a variety of religious dramas in the $10^{\text {th }}$ century. It is divided into a ceremony and a play, both of them performed in church. It was separated and removed from the church by the end of the $14^{\text {th }}$ century. Besides the passion there are the passion processions, the mystery, the miracle and the morality. The ceremonies, i.e. the short dialogue in Latin between angel and the Marias who found the empty tomb, were developed in Italy after the year 660 and they spread in France and onward in Spain, England and Germany, and then among Czechs and Poles. The ceremonies at the tomb included new characters and new scenes which were not in the Gospels. They contained elements of common folk language and thus they came up in the Easter (liturgical) plays. They could also contain comical elements with improperly dressed actors eating to excess in the scene of the Last Supper and provoking the audiences. The ceremony was first the part of the mass which later transformed into the Laud before mass. Between the $13^{\text {th }}$ and the $15^{\text {th }}$ century the liturgical drama gradually moved itself from the church to the church entrance. Singing was beginning to replace speaking in church discourse. The plays increased in mass, and there were more spectators as there were actors and other co-workers. They would count from one hundred to two hundred and increased the passion processions.

Events of the kind were organized from the $15^{\text {th }}$ century onward but most of them were performed during the $17^{\text {th }}$ and in the $18^{\text {th }}$ centuries. The play was transferred to various stages in the city squares, in front of important houses ... Latin was removed. The passion procession was not just performed under the directions of the members of the church. There were also the handcraft guilds and the special associations of the laymen. In the beginning women were not amongst the actors and their parts were performed by young men. The dumb processions of only still life scenes, the processions where scenes were interpreted, the processions with the correct dramatic spectacles and so on were developed. The most significant processions of that time are still preserved today, like the passions of Erl in Tyrol and Oberammergau in Bavaria. The latter goes back to 1622 with some intervals. The Prague passions indicated evident connections with the processions in Ljubljana and Škofja Loka. In all of them examples are in the background and in key stages the fraternities and the Capuchins. Passion processions were in Slovenia in Kranj, Novo mesto, Tržič, Ruše, Carinthia ... The first recitations flowed in the form of a solemn recitation of the Gospel's text in the melodic forms of the West Christian liturgy. During the $16^{\text {th }}$ and the $17^{\text {th }}$ century the singular recitation changed into the plural choir singing. In the Baroque the passion developed into great vocal-instrumental composition of choruses, arias and recitals, especially Johann Sebastian Bach (four Passions) and Georg Philipp Telemann. In Slovenia the first was Iacobus Handl Gallus (three motets' passions), and after him are the Slovene composers Stanko Premrl, Alojzij Mav, Franc Kimovec, Matija Tomc, Jože Trošt and others.

Škofja Loka Passion Play (ŠLPP) is one of the most important dramatic works in Slovenian. It is the oldest well kept dramatic text. It was mainly performed in the $18^{\text {th }}$ century (1715-1768), and several times until today. After a long time the ŠLPP emerged 
again as, "a phoenix from the ashes", in 1936 when (Škofja) Loka’s Tine Debeljak put it on stage. In its original form the ŠLPP was performed in 1999 in Škofja Lokas' streets and squares and repeated in 2000, 2009 and 2015. The producer in 1999/2000 was Marijan Kokalj, in 2009 Borut Gartner and the last time (2015) Milan Golob.

The ŠLPP has an exceptional cultural and historical value. This was confirmed by inscribing the ŠLPP into the register of life heritage by the Ministrstvo za kulturo RS/The Ministry for Culture of RS, in 2008. The ŠLPP was written as the first unit in this register. In 2016 it was inscribed into the UNESCO Representative List of the Intangible Cultural Heritage of Humanity as the first element of the intangible cultural heritage of Slovenia.

The dramatic text and the procession of the ŠLPP by the Capuchin monk Romuald Marušič from 1721 is accompanied by music: from its original and from the first installations of the ŠLPP which are less provable and is hypothetical. From the repertory of the Slovene Lenten songs we can find the Tolminski rožar/The Rosary of Tolmin as one of the possible probable "basis" for the ŠLPP. There is music as additions by Josip Čerin, Niko Kuret and Stanko Premrl and music contributed for the last and modern Škofja Loka procession renewals of the ŠLPP Andrej Misson and Tone Potočnik, for the statics arrangement of the ŠLPP in the Drama SNG/The Drama Slovene National Theatre in Ljubljana (2000) contributed folk singer Ljoba Jenče and the Slovene composer Aldo Kumar (b. 1954). There is a new composition of the ŠLPP in Ljubljana and Škofja Loka (2002) by the Slovenian composer Alojz Srebotnjak (1931-2010). The text is unitary: a diplomatic copy, simple phonetic transcription with translation of non Slovenian parts of texts of the Capuchin monk Romuald Marušič, based on all mentions of (new and modern) performances of music of the ŠLPP.

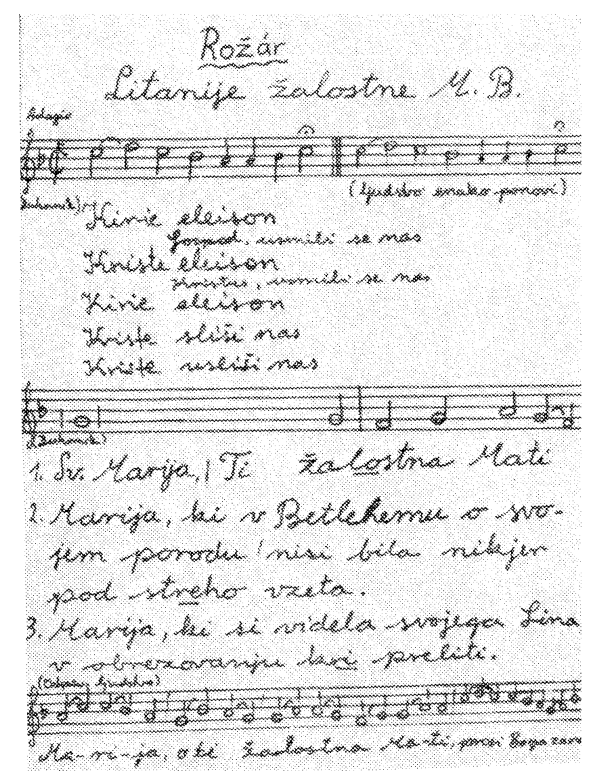

Fig. 1 The Rosary of Tolmin (Tolminski rožar) about the $15^{\text {th }}$ century (copy from the Tolmin Religious Journal, No. 2, March 1982, p. 1) 


\section{THE PEDIGREE - A REPERTORY OF THE SLOVENE FAST SONGS}

Lent (from Ash-Wednesday to the beginning of the mass of the Last Supper on Maundy Thursday) begins with the significant ceremony of sprinkling with ashes, according to these serious words: "To do penitence and let you believe in the Gospel!" or: "Remember man, that you are dust and to dust you will return!" The worship of God during Lent is preparing for the administering of the Holy Communion of the Easter mystery to catechists as to believers. At this time it transforms our spirit to the supernatural, spiritual worth. It is a time of grace and saving. Lent is not so much the time of the conferment of life than the time of deep life when we intend to hearken more and to give up more to the spurs of the Holy Spirit, to be more responsible and closer to the grace of God. The expiation and Christian life are closely linked together. Conviction of this comes from some facts of our past: by the end of the $9^{\text {th }}$ century the Salzburg synod asks the priests to provide for dignified folk singing and the worshiping of God, to Primož Trubar. In an introduction to his one book of songs from the year 1567 Trubar wrote about the importance of singing plays in the religious life. Singing, if correctly and religiously performed inclines the human heart to piety and to true pleasure: people become more pious and focus on prayer to listen to God's word and the receiving of the sacraments. Most of the merit for the (Slovene) church music goes to the bishops Tomaž Hren, Anton Martin Slomšek and Anton Jeglič, and Cerkveni glasbenik/Church Musician (1878-1945; repeatedly after $1976 \rightarrow$ ), among the composers then Franc Kimovec and Stanko Premrl. This enthusiasm for church music and the recommendation of folk singing would not have been successful if the Slovenes had not had a considerable number of composers whose spirit created true Christian and Slovene songs. As singing made the solemnity, the worship of God-s choir introduces us deeply into the secret of redemption and so on. In church music, that is in the folk or art music, we know vocal and vocal-instrumental compositions from the Bible - liturgical and other religious texts and the only church instrument, organ's music.

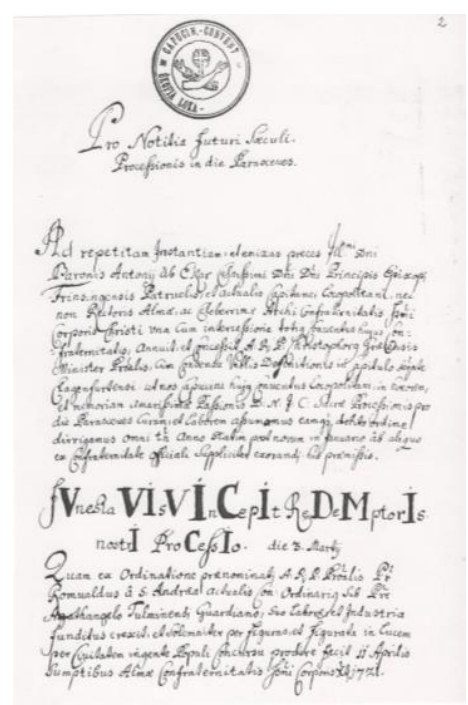

Fig. 2 The title page - the second numbered page of the ŠLPP, the dramatic text from the year 1721 


\section{TOLMINSKI ROŽAR/THE ROSARY OF TOLMIN}

It is only one of the "local" old Lenten universe and according to the title, it is closely, connected and processed from and kept in Tolmin. It is in the north-western region of Slovenia where the closed life and career of the Capuchin monk father Romuald Marušič (1676-1748), author of the first complete written and performed dramatic text of the ŠLPP began and ended. There are clearly defined (outside music) connections between Škofja Loka and Tolmin. It is in the secondary musicological, i.e. history of arts' parallels. These we can see in the mention of Tolmin in 1063 (Škofja Loka, 973), when in the $14^{\text {th }}$ century the earls of Gorizia took possession. These parallels can be found in the figural keystones of the forms of St. Ulric and St. Martin in the Carniolian-Škofja Loka's group of the stonecutting decoration of the presbytery as the best example of this type of monument in Slovene architectonic plastic art in the $10^{\text {th }}$ century in the branch establishment church St. Ulric in the churchyard under Tolmin. They keep fragments of frescos in the nave belonging to the first half of the $13^{\text {th }}$ century, but the altar's part was painted by the scheme of the Carniolian presbytery in year 1472 in northern style Middle Ages late Gothic art realism. For Tolmin alone there are significant other cultural and historical particularities of rich archeological history of art and ethnologic heritage. There is built The parochial church of St. Maria Assumption which is historically younger than Tolmin was built there in the $15^{\text {th }}$ century and it was known as a pilgrimage church. It was from this church that the prayer of Passion Week (on Monday-Thursday and Good Friday), rosar, for the pious Folk emerged.

This was the way to passion i.e. the art represented the passion of Christ or to the Golgotha-the part of the Gospel, which is described in liturgy on the way - perhaps then to Romuald Štandreški in the year 1721 in the ŠLPP is not far.

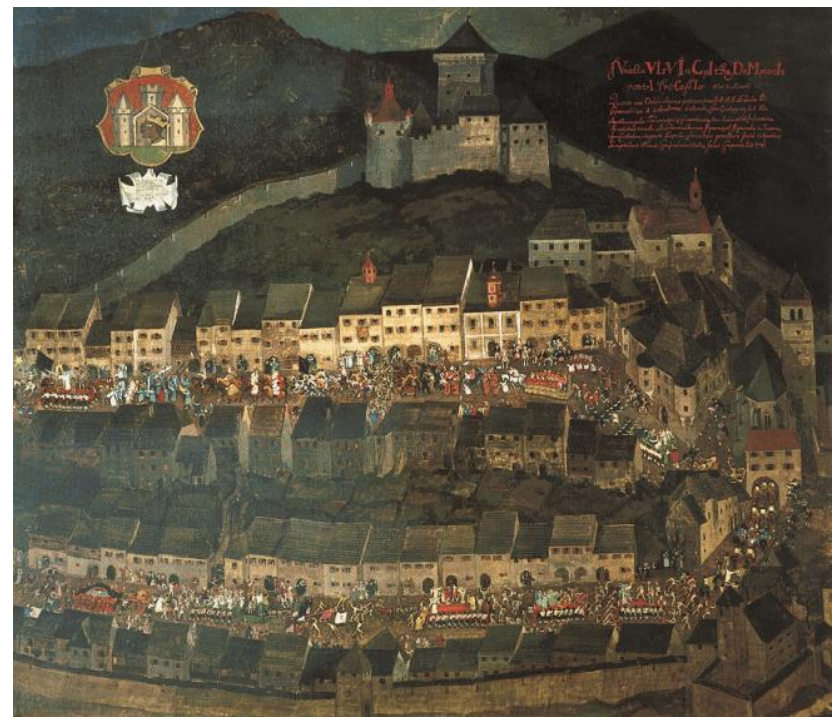

Fig. 3 The ŠLPP of author Boris Kobe, 1967, the canvas. It's saved in the Slovene Theatre Institut (Slovenski gledališki inštitut) in Ljubljana (in the Phototheck of the Škofja Loka Museum/Loški muzej) 


\section{... AND AGAIN THE ŠKOFJA LOKA PASSION PLAY}

The ŠLPP in Romuald's significant procession after 1782 (the prohibition of Maria Theresa) did not appear in the streets and squares of Škofja Loka. Therefore the ŠLPP "just" appeared in 1930 on the then Ljubljana Radio, on Palm-Sunday, one of its first electronic media created by Niko Kuret. For this occasion (still more for the following stage performances in Kranj, in the years 1932 and 1934) he alone, together with the composer and organist Stanko Premrl arranged and issued in print the text and the music pieces for the ŠLPP: the prologue, introduction, fourteen images and the final choir the Slovene-the ŠLPP (by the full dramaturgy, scenery, costume design, the directors' instructions and the preface words on page 62; Niko Kuret, Slovenski pasijon/The Slovene Passion, Kranj 1934) and Glasbeni vložki/The Musical Pieces (for the Slovene Passion on the 12 page; Stanko Premrl, Glasbeni vložki/The Musical Pieces, Kranj 1934). As it can be noticed in Kuret's introduction, in this case there are some examples of foreign models of the same procession elsewhere in the world. They kept differentiating the ŠLPP as up to that time period of development in degrees of music theatre (from $18^{\text {th }}$ century up to beginning of the $21^{\text {st }}$ century). In this context we can refer at least to the Easter play in Klostenburg (Austria), the passions in Alsfeld, Redentin, Trier and Freiburg (all Germany), and that which is the most referred to both of them (Niko Kuret and Tine Debeljak) and his collaborators, fellowpassengers and continuators of the various references statistical performance of the ŠLPP: in Oberammergau (Germany). Kuret and Premrl did not even elude the Passion of Jesus Christ from the year 1818, the work of Carinthian and Slovenian Andrej Šuster Drabosnjak: thus after the radio (electronic) premiere of the ŠLPP (on Palm-Sunday 1930) in Ljubljana were of main importance and demanded four stage performances in Kranj: March, 12, 13, 18 and 20, 1932. That is why in the Premrl's Glasbeni vložki//The Musical Pieces appeared the various titles of songs, the instrumental pieces, some of them new, others actually already known as Slovene church songs.

The new music for the new editions of the ŠLPP and the performances in the years 1999-2000, 2009 and 2015 were contributed by the composer and music pedagogue Andrej Misson (b. 1960) and the organist and music pedagogue Tone Potočnik (b. 1951) who were locals.

Furthermore we can mention two dramatic i.e. music treatments of the ŠLPP in Slovenia: after the original the Processione Locopolitana in die Parasceves performed as a premiere in Drama Slovenskega narodnega gledališča/the Drama of the Slovenian National Theatre in Ljubljana on December 16 2000: the author of transcription Jože Faganel, the director and author of scenarist Meta Hočevar, the costume designer Jasna Vastl, the dramatist Igor Lampret, the folk singer Ljoba Jenče (b. 1960), the composer Aldo Kumar (b. 1954), the choreograph Tanja Zgonc and others. " There is a "new" score by Slovene composer Alojz Srebotnjak Škofjeloški pasijon/The ŠLPP for (four) solo voices, the mixed choir and orchestra (1999-2000). ${ }^{2}$ This new music piece as an oratorio

\footnotetext{
${ }^{1}$ Video holder of Drama Slovenskega narodnega gledališča in Ljubljana; the recording of the stage, December 232000 (duration: $76 \mathrm{~min}$ ).

${ }^{2}$ The original and copies of score in four copies see in Društvo slovenskih skladateljev, committer (OE Glasbena produkcija RTV Slovenija, for Simfoniki RTV Slovenija) and composer A. Srebotnjak as a coproprietor then score as the choir score and parts for all referred performers. Video cassette of the first performance is property of Arhiv RTV Slovenija-Televizija Slovenija i.e. it's Uredništvo za resno glasbo in balet; the work for them recorded (Ljubljana, Cankarjev dom, March 8 2002) director: Dušan Hren, TV-
} 
type of music form performed for the first time in Ljubljana on March 8, 2002 in Gallusova dvorana/The Gallus Hall of Cankarjev dome, repeated in Mestni trg in Škofja Loka (June 29 2002). Nowadays the performances of the ŚLPP demanded or provoked quite a new, modern art language we can notice in the drama performance of Meta Hočevar only for the dramatic part (not for the music) and not for the other the contemporary music of Alojz Srebotnjak in his "church cantata," the ŠLPP. It is also normal that the composer used the new symphonic speech with the contemporary instrumentation and archaic views for the vocal parts of the soloists and the choir. For the first and for the second music we can establish that they become more and more integral part and constituent of the drama performance. In Srebotnjak's case they are then purely the main part, the main challenge and those are its results, too.

Quite new, now as a modern discography result which means the issue of Srebotnjak's musical work, the ŠLPP as a modern digital and permanent sound keeper, CDs i.e. by relative long music, score on two discs (CD; Škofja Loka/Ljubljana, Občina Šk. Loka/Radio Slovenija/Založba kaset in plošč RTV Slovenija, 2004). ${ }^{3}$ The ŠLPP issued together with composer's youthful work from the year 1965, Ekstaza smrti/The Ectasy of Death to the text of Srečko Kosovel.

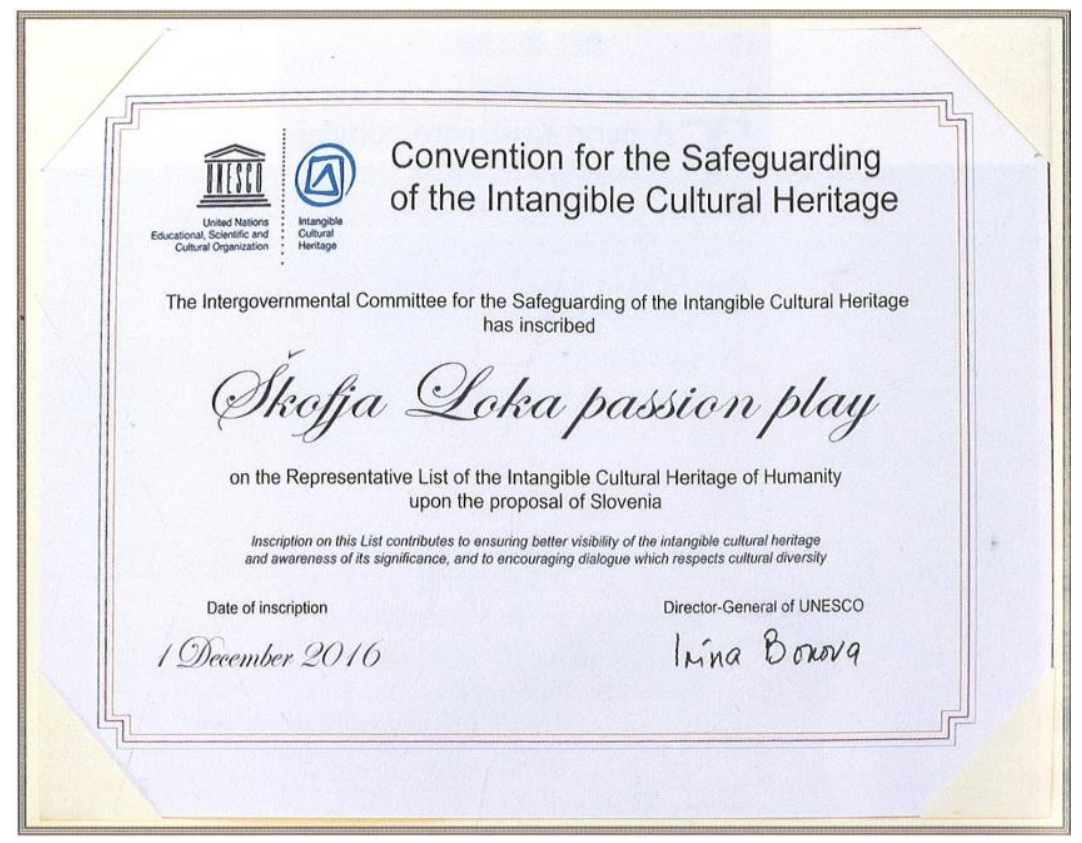

Fig. 4 The document about the inscription of the ŠLPP on the UNESCO Representative List of the Intangible Cultural Heritage of Humanity

redactor and producer Nada Marošek Tomažinčič, music producer Žiga Stanič, sound engineers Rado Cedilnik and Aljoša Ertl with co-workers; commentator Daniel Celarec.

${ }^{3}$ Franc Križnar: the text by the promotion cit. CDs (Škofja Loka, Log in Poljanska dolina, May 222004 , unpublished) by the title Škofja Loka Passion Play today. 


\section{CONCLUSION}

In the frame of mutual relations and the development of the ŠLPP we showed here not only the (very) beginnings of it in the Slovene Lenten songs but also the yearly procession of the ŠLPP expected on Good Friday or at the end of the Lent within the frame of the church year. The repertory of the Slovene folk and art songs is very rich. It is not amazing that the author of the ŠLPP father Romuald Štandreški, the Capucin monk who was later (1715-21) the author of the ŠLPP, did not know them. In the same sense "the scene music" or others in the ŠLPP would not used. We do not have any evidence for that, i.e. litany singing in the ŠLPP. Even then the music and folk singing in the ŠLPP were present because this proved then that Romuald's drama text of the ŠLPP as instructions to performers - yearly Easter procession. The church music then had already been present in Slovenia before the $18^{\text {th }}$ century. The church alone for all these centuries added to the development of festive, the worship of God choir and singing such as announcing deep secrets of the redemption. One of them most certainly is the Tolminski rožar. Today it can be found in Tolmin as a reminder of the litany, church Lenten songs. The author of the ŠLPP father Romuald Štandreški, the Capucin monk would know because he proceeded from then St. Andrea (in Gorizia, Italia) and returned again from Celje, Škofja Loka by the end of his own life and career to Gorizia Capucin cloister. Immediate union between the Tolminski rožar and the ŠLPP has not been proved. That does not mean that one or the other were influenced by the music dramaturgy of the ŠLPP. Romuald Štandreški (Lovrenc Marusič or Marusig) lived and worked in St. Andrea, Gorizia, Celje, Škofje Loka and Gorizia from 1676 to 1748 in the same places, in the Capuchin cloisters in Slovenia. Therefore in these frames the manuscript text of the ŠLPP as the most worthy work of the Slovene Barock literature even in that respect. We can add to this all other stage elements with the music as one of the most significant and the most emphatic. It is true that this influenced firstly the widespread taste of (folk) crowds, who collaborated as a whole representative or assisted the ŠLPP. This is the importance of the ŠLPP at the time of Slovene (dramatic, music, literature and so on) Baroque.

Slovene passion presents the Bible from Adam and Eve and their expulsion from paradise through various Bible scenes to the passion of Christ and Holy Sepulchre. From the modern music writings for the arrangement of the ŠLPP in 2000 and 2002 (both of them in Ljubljana), for the static, drama stage the ŠLPP in the Drama SNG (Meta Hočevar) as for the music "cantata" of Alojz Srebotnjak the treatment and unity of text are significant for the ŠLPP, as we know today from the diplomatic copy (simple phonetic transcription with translation non-Slovene texts). This means that the "music" suggestions based on the Marušič original from 1721, by today's modern transcriptions of text. After that there are the units of various (contemporary) music, as the drama stage as the "church cantata" - passion at the end. As the drama stage for that i.e. the drama has not encroached and not shortened the text in the whole version - (the original and some years later added) the musical pieces are now as secondary significance. On the contrary they are removed from significance and meaning, duration and finally from direct connection to music and text, which in the Srebotnjak case is quite different. Then, the composer uses the Marušič text, keeping to the whole (giving up some text and even whole scenes, images), in the form and content as we know in today's modern transcription (the text). When the composer decides that he by the text annexes and his own music text, the cantata, he does not quite give up and then he was in the opposition. 
It is true then all of installations and by the own attitude of images, the pictures in the whole 13 (numbers) are kept in all these examples only by continuance numbers of images and its titles, if not other. For both or all of the "music" works is important to notice the harshness, which is the same in all of them: sad, gloomy as from this text we expect. (The original) text of the ŠLPP refers to the number of musical instruments and the musicians, the playing (instruments) and singing. In all the further performances the ŠLP as a static (dramatic), the procession and/or the radiophone performances is the same, therefore the music, announces each time differently.

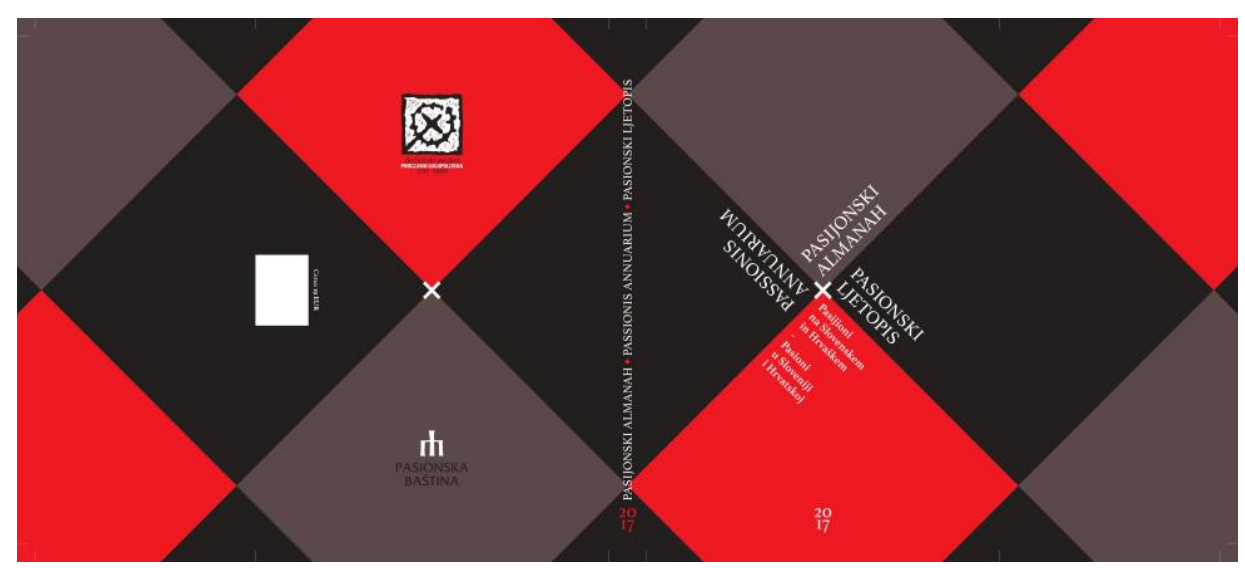

Fig. 5 The title page of the Passionis Annuarium (Škofja Loka, 2017)

\section{REFERENCES}

Cvetko, D. (1964). Stoletja slovenske glasbe (The Centuries of Slovene Music). Ljubljana: Cankarjeva založba. Gledališki list Slovenskega narodnega gledališča - Drame Ljubljana (Playbill of Slovene National Theatre Drama Ljubljana), No. 6, season 2000/2001, uprizoritev, December 5, 2000.

Križnar, F. (2010). Genealogija glasbene dramaturgije Škofjeloškega pasijona (The Genealogy of Music Dramaturgy the ŠLPP). Škofja Loka, Puštal: Zasebna knjižnica Antolin-Oman.

Romuald-Lovrenc Marušič, O. (2000). Škofjeloški pasijon (The Škofja Loka Passion Play), directed by Meta Hočevar, video recorded by Tone Stojko, recorded of performance December 232000,76 min.

Slovenske ljudske pesmi I in II (The Slovene Folk Songs I and II). (1997, 1981). Ljubljana: Slovenska matica.

Slovenske ljudske pesmi, junaške, zgodovinske, bajeslovne in pravljične pripovedne pesmi (The Slovene Folk Songs, Heroic, Historic, Mythological and Fabulous Prosaist Songs). (1996). Ljubljana: GNI ZRC SAZU.

Škofjeloški pasijon - diplomatični prepis (The Škofja Loka Passion Play - The Diplomatic Transcript). (1987, 1999). Ljubljana: Mladinska knjiga, Knjižnica Kondor, zvezek 238. 


\section{MUZIKA I PATNJA: PRIMER PASIJE IZ ŠKOFJE LOKE. PASIJA IZ ŠKOFJE LOKE U SAVREMENOM MEĐURELIGIJSKOM KONTEKSTU}

Nastanak Pasije iz Škofje Loke vezuje se za pesme koje su se pevale tokom velikog posta. Svake godine procesija prilikom izvođenja Pasije iz Škofje Loke odvijala na Veliki petak ili na kraju uskršnjeg posta. Repertoar slovenačkih narodnih i umetničkih pesama koje su se pevale za vreme velikog posta bio je veoma raznovrstan, ali je moguće da ih autor Pasije iz Škofje Loke, kapucinski monah otac Romuald Marušič (1715-1721) rodom iz Sant Andrea (Goricija, Italija), nije poznavao.

Ključne reči: slovenačke pesme u vreme velikog posta, procesija, otac Romuald iz Sant Andrea 